Revista Iberoamericana, Vol. LXX, Núms. 208-209, Julio-Diciembre 2004, 915-938

\title{
SOU MARGINAL! SOU HERÓI! O PERIODISMO CULTURAL NO ENTRELUGAR DO INTELECTUAL LATINO-AMERICANO
}

\author{
POR \\ JORGE H. WOLFF \\ Universidade Federal de Santa Catarina ${ }^{1}$
}

\section{REVISTAS COM SUPLEMENTOS}

Revistas supõem estratégias coletivas, não obstante seu caráter recorrentemente efêmero e molecular. Suplementos literários têm na base o ecletismo e uma constituição ao mesmo tempo coletiva e individual. As figuras aqui reunidas -entre revistas e suplementos, entre Argentina e Brasil, países situados no fio da navalha do dependentismo (para não dizer “desenvolvimentismo”), os pólos nacionalização/internacionalizaçãomanifestam certa originalidade de meios aliada a certa comunidade de fins, quero dizer, refletem os novos questionamentos de um momento de crítica, evidência e transição do campo cultural latino-americano, sob perspectivas teóricas similares mas com trajetórias diversas a partir de seu (não-)lugar: diaspórico e supostamente colonizado, no caso dos intelectuais brasileiros; nacionalista e meramente populista, no caso dos argentinos - entre outras “qualidades” em ambos casos, sob distintas formações sociais, políticas, culturais e semelhantes "estruturas de sentimento", postas em movimento a seguir.

As principais referências do ensaio encontram-se disseminadas em periódicos culturais latino-americanos de diversos portes, do jornal Opinião e o Suplemento Literário de $O$ Estado de S. Paulo às revistas argentinas Los Libros e Literal. As vertentes críticas postas em contraste por essa via determinam a circulação das idéias e a ordem dos discursos em questão. A exceção encontra-se na quarta parte, em que o conceito-chave do texto é lido mais detidamente, a partir de seu ponto de vista peculiar. Assim, no entrecruzar destes dispositivos de leitura, articulam-se novos lugares de enunciação, os quais colocam permanentemente em questão os ideais de pureza e de unidade, transformando, ou pretendendo transformar, o arsenal teórico-crítico de que se servem, com maior ou menor sucesso e radicalidade, bem como, no limite, o próprio contexto “neocolonial” em que se inserem.

\footnotetext{
${ }^{1}$ Agradeço à Capes e ao CNPq pelo apoio à pesquisa.
} 
II. CRÍTICA LITERÁRIA E VERDADE

\begin{abstract}
A única forma de se saber, com segurança, como será nosso mundo dentro de 30 anos é sobreviver para vê-lo. Eu felizmente não terei que fazê-lo. Morrerei em 1983.
\end{abstract}

Darcy Ribeiro ${ }^{2}$

Abordar o periodismo cultural latino-americano da década louca ou prodigiosa ${ }^{3}-\mathrm{e}$ da subseqüente- mais ou menos louca? mais ou menos prodigiosa? -desde a perspectiva hibridizante representada pelo conceito de entrelugar é, naturalmente, um gesto utópico situado entre a hierarquia e a anarquia, o alto e o baixo, o sublime e a abjeção, a intervenção e a invenção, o heroísmo e a dissolução. E particularmente em relação ao campo que nos ocupa: a literatura e a crítica cultural latino-americana sob o signo de 68, universo em transe com a forte emergência e a plena expansão da cultura massiva, que para alguns, a exemplo do autor de Verdade tropical, representou (e representa) um fenômeno altamente fértil, saudável, produtivo. Verifica-se de fato hoje que, se não tudo, quase tudo era verdade em relação ao futuro neoliberal do "país do futuro" -uma "nação falhada", segundo o retrospecto do poeta-cantor, em versão livresca e institucionalizante, marcada pela complacência, de uma história escrita e reescrita inúmeras vezes apesar de recente. ${ }^{4}$

Não haveria como, por outro lado, refazer a afirmação de uma floração das revistas, como um dia o fez a crítica Leyla Perrone-Moisés nas páginas do Suplemento Literário de O Estado de S. Paulo, referindo-se como de hábito ao universo cultural e intelectual francês: "O fenômeno mais característico da atividade literária francesa da atualidade talvez seja a floração das revistas”, afirma ela, abrindo o texto. Sendo a atualidade um dia de maio de 1970 e a sua visão atualizada, antes uma reportagem sobre um pujante mercado editorial, do qual pinçava três periódicos culturais que se tornaram tão cultivados quanto celebrados, sobretudo o último de sua lista -Change, Poétique e Tel Quel (“Floração” 1).

\footnotetext{
${ }^{2} \mathrm{O}$ antropólogo e escritor, morto no dia 17 de fevereiro de 1997, escreveu este texto, intitulado "Venutopias 2003", em 1973 por encomenda do jornal El Nacional, de Caracas, durante as comemorações de seus trinta anos, aparecendo depois em Postdata, de Lima, Ciencia Nueva, de Buenos Aires, e Opinião (7 março 1975), do Rio de Janeiro.

${ }^{3}$ Os anos 60 segundo, respectivamente, Caetano Veloso em Verdade tropical (ver nota 3) e P. Sempere e A. Corazón, autores de La década prodigiosa, 60, 70 (Madrid: Felmar, 1976), citado por Claudia Gilman (Entre el fusil y la palabra, cap. I).

${ }^{4}$ Verdade tropical é o memorial do ideólogo-mor do movimento tropicalista, desencadeado em 1967 e interrompido oficialmente dois anos depois, com o exílio londrino dos baianos. Os depoimentos autobiográficos sobre o período, como se sabe, jorram rios de tinta desde então. Em mais de 500 páginas, o poeta-cantor veste-se e desveste-se para dar sua versão da história da Tropicália, ou seja, do Brasil no período. Uma de suas principais conclusões sobre a nova ordem mundial é a que segue: "Hoje são tantas as evidências de que, por um lado, qualquer tentativa de não-alinhamento com os interesses do Ocidente capitalista resultaria em monstruosas agressões às liberdades fundamentais, e de que, por outro lado, todo projeto nacionalista de independência econômica levaria a um fechamento do país à modernidade” (52).
} 
No entrelugar descolonizante ${ }^{5}$ da América Latina, no entanto, a própria diferença surge necessariamente diferida. Não, é claro, pela graça de uma terra mágica, eleita pelos deuses para etéreos misticismos, prazeres ou sacrifícios, e sim por se tratar, antes de mais nada e segundo seus próprios protagonistas, de uma cópia transgressora-pós-vanguardista, pós-modernista-, de uma ruptura do modelo original, a qual convive além disso e desde sempre com a incerteza da mera existência. Haveria, assim, nos trópicos não uma floração mas uma estratégia de sobrevivência por vezes ao mesmo tempo parasitária e marginal -outras apenas marginal- em termos de periódicos culturais. Ou, usando uma metáfora mais bárbara, e talvez mais própria para uma revista ou um jornal feito por bárbaros novos, uma desfoliação de tipo vietnamita -procedimento de extermínio muito em voga naquele momento, vale lembrar. ${ }^{6}$ Ao contrário daquelas dos intelectuais sessentistas invariavelmente angustiados de Paris, e de seus epígonos locais, as empreitadas no terreno perigoso dessas deslocadas vanguardas tardias são obrigatoriamente heróicas, quer dizer, trazem coladas a si enquanto existam a marca de um vitalismo inexistente em terras mais firmes.

Seus rastros incertos merecem um breve resgate, antes de passar aos textos fundantes deste ensaio, assinados por brasileiros em algum tipo de exílio. ${ }^{7}$ À diferença da Argentina, o período que vai de fins dos anos 60 ao início dos 70 no Brasil é marcado, apesar e por causa da repressão (o violento Ato Institucional n 5 data de 13 de dezembro de 68), por uma nova onda de publicações culturais alternativas, que se situam politicamente à esquerda entre a literatura e a resistência à ditadura militar e respondem de algum modo à tensão entre cultura e massificação, literatura e verdade, dependência e liberação. ${ }^{8}$ Se na Argentina dos anos 50 a revista Contorno funcionou como principal modelo para o periodismo cultural dos anos subseqüentes, no Brasil a revista Clima, fundada em São Paulo ainda nos 40 por Antonio Candido, influenciou a maior parte das revistas e suplementos nascidos depois. A Revista Civilização Brasileira, criada em 65 e maior representante da esquerda nacional (incluindo nomes como Octavio Ianni, Francisco Weffort, Antonio Houaiss, Paul Singer, Ferreira Gullar, Fernando Henrique Cardoso e Nelson Werneck Sodré), pioneira nos debates sobre indústria cultural e cultura de massas no país, fecha suas portas ainda em 69, e o Suplemento Literário de O Estado de S. Paulo, cuja linhagem uspiana hegemônica realiza um trabalho de canonização do modernismo brasileiro e uma crítica de tipo sociológico e dialético (Barros Camargo 4), vive seus estertores. Já a revista Tempo Brasileiro, lançada em 1962 por Eduardo Portella e ainda

\footnotetext{
${ }^{5}$ A expressão se insinua em diferentes textos de Silviano Santiago, mas aparece efetivamente em sua "aula" de 1974 sobre a vanguarda ("Vanguarda: um conceito" 117).

${ }^{6}$ Ver a respeito em Los Libros n ${ }^{\circ} 18$ (abril 1971): “La guerra química. Efecto de la defoliación sobre la vida humana" (9).

${ }^{7}$ Refiro-me a "Situación del teatro brasileño", de Augusto Boal, em Los Libros n 15-16 (jan.-fev. 1971), e "O entrelugar do discurso latino-americano", de Santiago, apresentado no Canadá em março do mesmo ano e publicado pela primeira vez, salvo engano, na versão inglesa ("Latin American Literature” 1-19), da qual me utilizo na conclusão deste trabalho.

${ }^{8}$ Para este breve panorama, devo noventa e nove por cento dos dados relativos ao Brasil a Maria Lúcia de Barros Camargo, autora de "Atividade crítica e periodismo cultural no Brasil contemporâneo", ainda inédito. Quanto às informações sobre a Argentina, concentram-se particularmente em 30 años de revistas literarias argentinas (1960-1989), de José M. Otero.
} 
em atividade, é de extração universitária e se apóia sobre uma vaga ideologia de desenvolvimento nacional para esconder suas tendências a um tempo modernizantes e reativas, que explicariam a sua longevidade. Com a forte onda de repressão posterior ao AI-5, surge a necessidade das artes da dissimulação para escapar à censura. É o momento da explosão da chamada imprensa “nanica”, a começar pelo carioca O Pasquim (1969-85), que se utilizava do humor para fazer política e era simultaneamente crítico e veículo da contracultura. Um dos representantes mais decididos desta última tendência, a revista Navilouca (1972), teria apenas um número. Encabeçada pelos poetas Torquato Neto e Wally Salomão, foi uma espécie de continuação do tropicalismo, em banquete anárquico que incluía não só literatos como músicos, cineastas e artistas plásticos. Outra publicação contracultural do período, menos apocalíptica e mais integrada, foi a versão brasileira da revista Rolling Stone, dirigida por Luiz Carlos Maciel. Destaque-se, em sua edição de 2 de maio de 1972, uma longa e delirante entrevista londrina de Jorge Mautner com Caetano Veloso, provocativamente intitulada “Caretano”. Já o jornal carioca Opinião, ativo entre 1972 e 77, representou o outro lado da moeda da cultura sob a ditadura, divulgando em suas páginas os debates universitários em torno do estruturalismo e da teoria literária e atuando sob forte censura, uma vez que pertencia a intelectuais e políticos então de oposição. Na Paulicéia, a intelectualidade ligada à USP faz uma nova tentativa de intervenção periodística entre outubro de 73 e fevereiro de 74, com os quatro números de Argumento (o último dos quais foi apreendido e sequer chegou a circular), mais argumentativa e menos panfletária do que a Civilização Brasileira, de onde vinham vários de seus colaboradores, como Weffort e Cardoso. A partir de 1975, novos periódicos de cultura continuam a aparecer, entre os quais as revistas paulistas Escrita (dedicada sobretudo à divulgação de escritores brasileiros) e Almanaque (em nova investida uspiana na linhagem de Clima), a mineira Inéditos e as cariocas Ficções e José.

A propósito da Argentina, "la década del '70 no debe considerarse muy fructífera en la creación de nuevas revistas literarias”, segundo Otero (95). Verdadeira ou não, talvez esta opinião sirva para justificar a postura de um Jorge Warley, que em "Revistas culturales de dos décadas (1970-1990)”, apesar de considerar o período fértil para o setor, opta finalmente por abordar apenas duas revistas da primeira metade da década, Los Libros e Crisis (197). Em um contexto sócio-político cada vez mais conturbado, mas com uma indústria editorial ainda pujante, aproveitando a maré vazante do boom, a revista Los Libros (1969-76) aparece como mais um periódico cultural encontrável em livrarias e quiosques (com tiragem média de quatro mil exemplares), já que erradicados das universidades. Para mencionar alguns de seus interlocutores, de um modo ou outro presentes em suas páginas, a revista Crisis (1973-76, em primeira “dentição”), ${ }^{9}$ dirigida por Eduardo Galeano -proveniente de Montevidéu e do semanário Marcha-, representava a esquerda populista e nacionalista, reivindicando amplamente o latino-americanismo e atingindo grandes tiragens (20 mil exemplares em média). Entre os intelectuais presentes simultaneamente em Los Libros e em Crisis, para dois exemplos, incluíam-se Ricardo Piglia (diretor por um momento da primeira) e Aníbal Ford (idem em relação à segunda).

\footnotetext{
${ }^{9}$ Referência indireta do A. ao termo utilizado por Oswald de Andrade, na Revista de Antropofagia,
} de "primeira” e "segunda" dentições, para indicar a primeira época da revista Crisis. [N.E.] 
Se nos anos 60 muitas revistas culturais argentinas importantes abriram e cerraram suas portas, a exemplo de Hoy en la Cultura (1961-66), La Rosa Blindada (1964-66) e Primera Plana (1962-69), El Escarabajo de Oro, dirigida por Alberto Castillo desde 61 (como sucessora de El Grillo de Papel), sobreviveria até 1974. Seguia uma linhagem de existencialistas tardios, permanecendo portanto até o fim como uma revista típica dos anos 60. El Escarabajo de Oro, no entanto, ainda daria novas mostras do fôlego sartreano, ao ganhar uma sobrevida a partir de 77 com El Ornitorrinco, dirigida por Liliana Heker ao lado do mesmo Castillo (até 86). De fatura oposta -quer dizer, igualmente militante, mas lacaniana-, surge em 73, como dissidência de Los Libros, a revista Literal, o periódico não-periódico de Germán García, Luis Gusmán e Osvaldo Lamborghini, posicionado, de forma deliberadamente perversa e marginal (como destacaremos adiante), no lugar indecidível de uma certa vanguarda literária portenha. Já Nuevos Aires, que publicou onze números entre 1970 e 73, teve direção de Gerardo Mario Goloboff, que também colaborou em Los Libros, sendo-lhe ideologicamente bastante próxima em sua perspectiva esquerdista revolucionária. Um de seus colaboradores foi Piglia -que em 1965 editara, aliás, o único número da revista Literatura y Sociedad, também tributária do existencialismo. E, no campo da cultura pop -não menos significativa para a noção de entrelugar do discurso latino-americano em discussão-, a Argentina tampouco ficaria atrás: Contracultura (1970-71), dirigida por Miguel Grinberg (que fora editor, entre 1961 e 69, dos treze números da revista “interamericana” Eco Contemporáneo, assumidamente beat e hippie), se propunha como "foro de alternativas”, mas acabou conhecendo apenas quatro edições.

\section{BANQUETE TRANSNACIONAL}

Se o Suplemento Literário de O Estado de S. Paulo não representava nenhuma "alternativa”, sendo seu exato e extremo oposto por estar embutido em um grande jornal de tradição liberal-conservadora, refletia-a necessariamente, amplificando o debate teóricocrítico nucleado na USP por uma via massiva e comercial. O próprio suplemento alimentou constantemente a relação com o periodismo através de uma seção semanal intitulada “Revista das Revistas”, a cargo de Livio Xavier, um crítico em geral reativo mas sempre atento à circulação internacional de periódicos literários e culturais em língua inglesa e francesa, além de portuguesa e espanhola. A influência do Suplemento Literário, que vive seu auge até a primeira metade dos anos 60 e que sobrevive por mais uma década, é bem conhecida, do mesmo modo que seu hábito das citações em francês, no original, ali onde a "floração das revistas" aparece de maneira progressista, se não imperial. ${ }^{10}$

Apesar das disparidades estruturais, as publicações de pequenos grupos de escritores independentes que se pensavam grandes também respondiam a tamanha febre global -vale dizer, ocidental- de esclarecimento e de confronto em torno da materialidade das

\footnotetext{
${ }^{10}$ Idealizado por Antonio Candido como um misto de suplemento com revista, sua equipe eclética de colaboradores, dirigida por Décio de Almeida Prado desde o início, em 1956, até 67, contava com, entre outros, Carlos Drummond de Andrade, Paulo Mendes Campos, Otto Maria Carpeaux, Anatol Rosenfeld, Sábato Magaldi, Augusto e Haroldo de Campos, Décio Pignatari, Bóris Schnaiderman, Fábio Lucas, Benedito Nunes e Vilém Flusser.
} 
idéias, bem como da vontade de compromisso, enfrentando semanários e suplementos de grandes veículos de imprensa com o melhor de que dispunham: as maneiras invariavelmente contestatárias, os métodos invariavelmente desafiadores. A revista Los Libros, surgida em 1969 -e ocupando uma trincheira aberta pela repressão nas universidades, à maneira (simetricamente inversa: como desrepressão) do Suplemento Literário paulistano, criado para suprir outra falta, a de uma boa revista que representasse a inteligência paulista, em contraposição aberta aos cariocas-, era ela mesma filha bastarda desta floração mundialmente influente, através da empresa bem calçada de um intelectual cordobês, Héctor Schmucler, ao lado de Ricardo Piglia, que sugeriria incluir o nome de Nicolás Rosa, crítico literário e tradutor de Barthes (como Perrone-Moisés, como Sarlo, como Santiago). ${ }^{11}$ Após militar sob o influxo de Antonio Gramsci (e de Juan Perón) na revista Pasado y Presente, Schmucler desembarca na França e cultiva a idéia enquanto assiste aos seminários de Roland Barthes: a princípio, na superfície, simplesmente La Quinzaine Littéraire ${ }^{12}$ em castelhano. Essa seria portanto a razão da recusa inicial de Piglia para integrar seu conselho diretor, atuando somente nos bastidores até 1972, quando Schmucler deixa a revista e Piglia assume-a ao lado de Beatriz Sarlo e Carlos Altamirano. Sua primeira etapa é tida como “estruturalosa”, na expressão de Jorge Onetti na própria revista (nº 10), ou como "ressacralizadora do nada”, conforme Wouter Bosteels a propósito de Oscar del Barco (Bosteels 428-31). Estas posições não podem, no entanto, ser vistas como unânimes, já que nem tudo nela é "ahistórico" ou “absoluto” mesmo nesse momento. Em "La crítica argentina y el discurso de la dependencia”, Jorge Panesi problematiza a influência do estruturalismo francês - "la picazón estructuralista, por asincronía entre países centrales y periféricos, ya venía con su remedio incluido, con una crítica ideológica posterior" (39)- e questiona seu suposto ecletismo inicial (43).

\footnotetext{
${ }^{11}$ Em entrevista colhida em Buenos Aires, em 1998, diz Piglia: "Yo conocía un artículo de Rosa sobre Cabrera Infante que me había gustado mucho, en una revista de Rosario, y cuando empezamos a ver con qué gente podíamos hacer, pensamos también en Nicolás Rosa. Lo cierto es que la hacíamos al principio Schmucler y yo, porque yo estaba contratado por la gente que hacía la revista [Editorial Galerna, de Guillermo Schavelzon] pero yo no quise aparecer porque la revista me parecía muy ecléctica. Entonces le dije a Schmucler: yo trabajo contigo pero yo no voy a aparecer ahí, porque la revista en ese momento era una revista digamos que no tenía una línea definida, era una revista más bien para crear un clima de discusión. Basicamente el objectivo era discutir con la cultura de masas, centralmente era hacer una revista alternativa a los suplementos de los diarios, a los suplementos culturales de los diarios, atacar el modo en que los diarios estaban ocupándose de la literatura, ¿no? Eso fue lo que la revista hizo en todos sus primeros años, tres o cuatro primeros años, ayudada por la aparición del estructuralismo y por lo tanto con la renovación de la crítica literaria, que nos permitió a nosotros criticar el tipo de crítica impresionista y comercial que se hacía” (1-2).

${ }^{12}$ A revista do editor Maurice Nadeau havia recém-estreado, em 1966; em 2001 completou 35 anos em plena atividade. Leyla Perrone-Moisés resgatou recentemente a longa trajetória de Nadeau, de 90 anos, para a Folha de S. Paulo (“Guardião do templo” 12-15): “Ter uma longa existência não é um mérito-diz a crítica paulistana-, mas uma sorte. Entretanto atingir uma idade avançada tendo participado ativamente da vida intelectual e política de seu país, durante mais de meio século, e ter conservado tal integridade, é um feito merecedor da maior admiração. De fato, não houve acontecimento político ou literário do século 20 francês em que Nadeau não estivesse, de alguma forma, presente" (12).
} 
Pouco a pouco a revista torna-se mais e mais intervencionista e, simultaneamente, à mercê dos acontecimentos políticos do presente, em missão supostamente redentora e regeneradora, ao menos segundo os cálculos de uma estratégia tão debatida quanto malograda. A desfoliação da revista, isto é, no caso de Los Libros, sua gradativa transformação em instrumento partidário e seu deslocamento rumo à barbárie política, contudo, não só ocorre de forma irreversível como revela surpresas, algo do caldo do pretérito e do futuro enquanto formação cultural, passando "de Tel Quel a la Marcha Peronista”, como deporia duas décadas depois Germán García, um de seus protagonistas. ${ }^{13}$

É o sinal de uma extraordinária fermentação teórica, anunciava então PerroneMoisés no Suplemento Literário do mais tradicional diário brasileiro, aonde começou a falar francês ainda no fim dos anos 50, divulgando o roman nouveau -para dizê-lo arrevesadamente, isto é, ao modo do crítico Brito Broca, seu predecessor na seção "Letras Francesas”. Com a morte do velho e bom crítico, ocorrida em 1961, a literata e pintora paulistana ${ }^{14}$ assume a seção, em favor das tendências modernizadoras da cultura européia e de seu mainstream, e em oposição à linha conservadora e sem concessões de Brito Broca, ${ }^{15}$ do qual herdaria ao menos a disposição interpretativa homogênea, embora mais concessiva, dentro de uma estratégia progressista-vanguardista particularmente problemática. Quando relacionada com a vertente tropical-antropofágica-o que, exagero ou não, fica como hipótese-, a modernização à francesa parece carregar em si o peso da própria tradição logofonofalocêntrica ocidental.

Um exemplar desviante desta tendência nas mesmas páginas do suplemento ilustrado do Estadão -mas poderia ser no carioca Opinião, ou no Suplemento Literário do (Diário Oficial de) Minas Gerais-, situado não menos estudada e estrategicamente entre os territórios da crítica e da ficção, é o Santiago de “O banquete”, pequeno texto que viria a finalizar o livro de mesmo nome, em alguma medida conto (como tudo aquilo que chamo conto), com nada de conclusão, talvez algo de posfácio. ${ }^{16}$ Vivendo entre Estados Unidos e França e enviando artigos esporádicos em qualquer gênero (entre um e outro) para o Brasil, publica no suplemento paulista desde "Eça, autor de Madame Bovary” (março de $1971)^{17}$ até os “Dois poemas do abraço” (junho de 1967) e “O Banquete” (5 de outubro de 1968) -este com direito a epígrafe dadaísta, de Tristan Tzara (conservada no livro), segundo o qual a lógica é uma complicação, a lógica seria sempre falsa, oferecendo aí as primeiras pistas de seu próprio posicionamento crítico e como que epigrafando o retorno

\footnotetext{
${ }^{13}$ O escritor, psicanalista e "inventor" de Literal discorre derramadamente sobre o período em "El exilio de escribir”, texto publicado na revista Hispamérica nº 59 (1991), lançada por Saúl Sosnowski nos Estados Unidos em 1973 e, a exemplo de La Quinzaine Littéraire, ainda hoje em plena atividade. ${ }^{14}$ Perrone-Moisés estudou pintura com o artista húngaro Samsor Flexor na São Paulo de fins da dos 50, exercitou-se no abstracionismo geométrico e chegou a participar de exposições coletivas e a ilustrar textos para o Suplemento Literário (Entrevista 1).

${ }^{15}$ Ver Santiago: "Lenha na fogueira” (61-2).

${ }^{16}$ Em 1970 o escritor publica os poemas de Salto (Belo Horizonte: Imprensa Publicações), além dos "textos" de $O$ banquete (Rio de Janeiro: Saga).

${ }^{17}$ Um de seus textos ensaísticos mais importantes e reveladores (desde o título), escrito em inglês em 1970 e incluído em Uma literatura nos trópicos. Está em franco diálogo com o ensaio sobre o entrelugar, que deve ser lido como um seu desdobramento.
} 
do debate modernista em 1972, a exemplo do que fizera no breve ensaio "Camões e Drummond”, publicado nos Estados Unidos seis anos antes (e, posteriormente, no SLMG).

No texto conclusivo de sua reunião de relatos celebrava um presente de outro crítico mineiro, Alexandre Eulalio -dom este que Santiago chama de "mapa do papiro", em referência ao manuscrito de parte de Les faux-monnayeurs que o leva à França, em busca de formação intelectual na metrópole-a exemplo do fundador de Los Libros -mas de olhos bem postos nas maneiras de um Oswald de Andrade, que descobre o Brasil em Paris em favor do aprofundamento de sua própria verve barbarizante e ferina e em nome de um vanguardismo errante por definição. Do mesmo jeito, diria-se que mais tarde Santiago descobre o Brasil, na voragem da história recente, ao nova-iorquinizar-se $e^{18}$ (mas apenas depois de Paris). “O banquete” é, portanto, o banquete da razão antropofágica na geléia internacional.

IV. Pierre Menard, Autor de Em liberdade

Creio que já houve períodos piores para a literatura, como os anos entre 68 e 72 .

Graciliano Ramos ${ }^{19}$

Em torno de 1970, Silviano Santiago propõe uma série de ensaios de interpretação nacional e continental através de leituras da literatura latino-americana, à luz da teoria crítica francesa, entre (principalmente) Claude Lévi-Strauss e Jacques Derrida, que se querem bárbaras e não "simplesmente” galomaníacas. É o que se lê na advertência ao derradeiro ensaio de Uma literatura nos trópicos, "Análise e interpretação": "Não se confunda, por obséquio, redução do campo de estudo a determinado grupo, cujo único fim é o de melhor (esperamos) apreender as idéias, com uma simples galomania” (202). Seu "manifesto", no entanto, é o conhecido texto de abertura, "O entrelugar do discurso latinoamericano”, espécie de fábula identitária paradoxal, porque fala em nome da produtividade da repetição e da diferença, do acaso e do inconsciente, propondo um para-além da perspectiva dependentista dominante. Vale dizer, contra uma perspectiva datada, propõese outra, avançada, ou "de vanguarda”, embora necessariamente lance mão de um certo vocabulário de época na versão original, que seria sutil mas significativamente matizado, como se verá.

\footnotetext{
${ }^{18}$ O neologismo aparece no início de um de seus romances, ambientado nos Estados Unidos em 1969, mas situado entre as Américas do Sul e do Norte: Stella Manhattan (20). G. Yúdice verteu-o ao inglês (Durham: Duke University Press, 1994); G. Leibrich ao francês (Paris: Metaillié, 1993). Paulo Leminski - em outra ponta da "tropicália" - também transformou em verbo certos conhecidos nomes próprios na introdução de um poema sem título de Caprichos \& Relaxos: "pariso/ novayorquizo/ moscoviteio/ sem sair do bar// só não levanto e vou embora/ porque tem países/ que eu nem chego a madagascar" (90)...

${ }^{19}$ Graciliano, como se sabe, é o autor de Em liberdade (1981), escrito por Santiago. A frase aparece em entrevista de Vale quanto pesa (199), sua segunda coleção de ensaios.
} 
O conceito de entrelugar constitui há já bastante tempo um lugar comum no campo da crítica cultural em sua versão brasileira e latino-americana (encontrando eco até hoje também, como é sabido, entre a intelectualidade da América do norte). No entanto, ou por isso mesmo, é fartamente empregado enquanto lugar pacífico, moeda corrente do discurso do intelectual dito latino e americano, em processo de naturalização que significa rigorosa negação do próprio conceito. De modo que -já que também nos submetemos a sua força desde o título- seria necessário lê-lo em chave igualmente bárbara e crítica, ou seja, no marco de transgressão que lhe é inerente, buscando suas principais bases teóricas entre a América austral e a Europa do oeste: de um lado os modernismos brasileiro e hispanoamericano (em seus diferentes momentos), e de outro lado o que se usa chamar, de modo não menos generalizante, a teoria crítica francesa -mãe e filha bastardas do vanguardismo sessentista, reunidas na maré montante, a um só tempo destruidora e afirmativa, da pósmodernização. Afinal, como se sabe, ou se deveria saber, Pierre Menard escreveu o Quixote e Eça de Queiroz, Madame Bovary.

O ensaio, escrito originalmente em francês no início de 1971, é dedicado a Eugenio [Donato] -e Sally-, um dos introdutores do estruturalismo nos Estados Unidos da América, e de certa maneira também na América dita latina, uma vez que aquele que seria um dos principais responsáveis por sua difusão no Brasil (em versão renovada) aprendeo a partir dele. Ao lado disso, vale recordar que Santiago cunhou -quer dizer, tresleu, ruminou, traduziu, devolveu-a expressão para o título de uma conferência apresentada no Canadá a convite do mesmo Donato, o qual no entanto o faria modificar por causa justamente de sua singularidade, rebatizando-a como "La naissance du sauvage, anthropophagie culturelle et la littérature du Nouveau Monde”, em inesperado lance “colonizado" de um intelectual usualmente mais do que up to date, segundo diria o próprio autor do ensaio. ${ }^{20}$ Posteriormente, como um simples título -quer dizer, em toda sua complexidade, ao abrir a coletânea significativamente subtitulada Ensaios sobre dependência cultural, reunida em 1977, publicada em 78, incluindo textos a partir de 68-, disseminou-se de maneira sem dúvida produtiva. Mas em certo sentido -e retomarei o ponto- o lugar intersticial em questão, no texto como na entrevista citada, não passa de uma ficção autobiográfica, ou seja, precede e excede o seu próprio sujeito, revisto aqui através do espelho do futuro:

(...) um brasileiro, professor de francês, numa universidade americana. Que foi uma das razões pelas quais eu voltei ao Brasil, porque minha esquizofrenia tinha chegado a um ponto que não agüentava mais... Eu não falava mais português, não é? Quer dizer, o português deixou de ser uma língua, para mim, de utilidade. E eu tenho a impressão que deve ter surgido desse caos, entende?... Foi um conjunto de conferências que Donato organizou, que foi como [professor]-visitante para Montreal... E ele me convida -e realmente foi um luxo para mim na época, porque foi [René] Girard, [Michel] Foucault e eu [risos]... Eu acho que era um pouco o enfrentamento da minha própria condição... de não ter um lugar- eu não tinha literalmente um lugar... (Entrevista 6-7)

\footnotetext{
${ }^{20}$ Entrevista (7). Se diria que Santiago inventou o termo em 71 assim como o crítico de artes Mário Pedrosa "inventou" a arte "pós-moderna” em 1965 -a propósito, aliás, de Hélio Oiticica, principal referência artística do primeiro à época.
} 
O poeta-professor transgressivo, o new leftist brasileiro na América durante os anos loucos, vai construindo assim, à maneira desconstrutiva, o seu próprio locus, que vem a ser -para empregar um jargão festivo- o lugar (louco) da "folia” do texto, ${ }^{21}$ sob a forma de uma prosa carnavalesca e a idéia-mãe de uma imaginação do paradoxo. Mas, para além das belas palavras, através do entrelugar, ou de uma "dialética rarefeita”, busca-se “a ‘explicação’ da ‘nossa constituição’ (vale dizer da nossa inteligência)”. ${ }^{22}$

Há então o que se poderia chamar, dobrado o ano 2000, duas tradições em uma neste texto manifestário. Os americanos austrais são argentinos antes de tudo cosmopolitas, Cortázar, Borges, tornados mais e mais célebres (ou celebrados) durante a década de 60 . A grande fonte tupiniquim é conhecidamente modernista e andradina 1922, que marca a cultura brasileira para sempre com as primeiras reivindicações radicais de modernização e hibridização - com seu famoso gesto fundador, tido como ainda excludente e não copulante: "tupi or not tupi, that's the question"23- e a introduz definitivamente no novo século XX. É Oswald de Andrade, artista e "proletário” vanguardista, quem propõe no início dos anos 40, em plena guerra mundial, a mulatização da Alemanha, gesto do qual Santiago não abdicará -ao contrário. ${ }^{24}$

De França vêm os assim chamados filósofos da descolonização no papel de teóricos quase indiferenciados, ignoradas no ensaio polêmicas e hostilidades, suas diversas posições -deliberadamente? até que ponto?- neste vasto campo que o hábito ou a moda denominaram “estruturalismo”, com ou sem prefixo e chame-se ele Lévi-Strauss, Lacan, Foucault, Barthes ou Althusser. Em Québec, fronteira franco-americana, cujo ambiente político era tenso, perturbado e propenso ao debate, ${ }^{25}$ falava um positivo admirador de

${ }^{21}$ Em tradução bárbara do termo francês "folie", a partir do enigma da "participation sans appartenance”, própria dos gêneros literários, segundo Derrida (“La loi du genre” 256).

${ }^{22}$ Em outro desdobramento da mesma reflexão, o texto "Apesar de dependente, universal”, de 1980 (em tom fortemente crítico diante da "lenta” abertura no Brasil), é posta em epígrafe uma frase de Paulo Emílio Salles Gomes: "Não somos europeus nem americanos do norte, mas destituídos de cultura original, nada nos é estrangeiro, pois tudo o é. A penosa construção de nós mesmos se desenvolve na dialética entre o não ser e o ser outro" (13).

${ }^{23}$ No entanto, o próprio Santiago demonstraria o contrário, desde o primeiro manifesto, de 1924, em um prefácio ("Fazendo perguntas com o martelo") a um livro de Gilberto Vasconcellos (Música popular: de olho na fresta, 1977), no qual define o tropicalismo como a soma de Dadá com Oswald: "É mais do que curioso notar que não existe a conjunção ou no Manifesto Pau-Brasil; encontra-se ela esmagada pela conjunção $e$. O problema para Oswald é o de manter relações críticas entre todos os elementos, relações estas que acabam por exprimir a contradição inevitável entre os diversos componentes desse insustentável todo. O elemento já não se exprime em sua pureza (por exemplo: quando se o julga em separado), mas pelo que nele se deixou contaminar pelo seu oposto e pelo que nele contamina o seu oposto" (6).

${ }^{24}$ Sobre a mulatização alemã, ver "Sol da meia-noite". Em prefácio a Ponta de lança, reunião de crônicas jornalísticas oswaldianas de 1943 e 44, Santiago reatualizaria suas idéias no sentido do pluralismo, oferecendo uma versão politicamente correta do incorreto e iconoclasta Oswald de Andrade (ver "Sobre plataformas e testamentos").

${ }^{25}$ Como em toda parte, nos grandes centros urbanos e universitários, naquele momento. A marca distintiva do evento canadense é que De Gaulle havia acabado de passar pelo país, pregando "Vive le Québec libre". 
Tristes tropiques, vale dizer, era antes o antropólogo de Le cru et le cuit que o filósofo da Grammatologie a ser interpelado-homenageado então. O próprio escritor afirmaria em seu depoimento não ter ainda uma leitura suficientemente atenta de Derrida (Entrevista 6). Distância que seria reduzida em breve.

O texto é introduzido -lembro- com um exemplo famoso de uma pretensa barbárie aos olhos ocidentais: os Essais de Montaigne e o conhecido capítulo sobre os canibais do Novo Mundo, que não são, segundo um rei antigo, de nenhuma maneira bárbaros. ${ }^{26}$ Estimulado pois pelo "canibal letrado", ao mesmo tempo que empregando algo do tom entusiasta típico dos libelos vanguardistas, Santiago vislumbrava então $a$ possibilidade de inversão (senão de tresvaloração) dos valores. Anos depois, através de uma nota de pé de página no início do texto, superpõe para a edição em livro uma passagem de L'écriture et la différence (uma vez transposta aquela distância), que faz menção à contribuição da etnologia para o descentramento da cultura européia hegemônica. Obviamente a "etnologia" é Lévi-Strauss nos anos 60, e Tristes trópicos espécie de bíblia sagrada da consciência culpada de uma pequena-burguesia ecologicamente correta, então nascente e em franca expansão. O ensaísta brasileiro irá se apoiar sobre a pesada nostalgia lévi-straussiana sem se colocar qualquer tipo de problema, a companhia Derrida-Lévi-Strauss era ponto pacífico -algo à maneira do que costuma ocorrer com o sobredeterminado lugar em questão. E, no entanto, neste mesmo livro seminal, Derrida livrava seu combate contra a tristeza de fato pouco tropical do eminente etnólogo -combate o qual, no entanto, Santiago tampouco deixará de exercitar.

Confrontados o primeiro ensaio de Uma literatura nos trópicos e o último, antes mencionado, o estudo “Análise e interpretação” (1975) -pensado a partir de teorias de Barthes e Derrida, em primeiro plano, além de Deleuze e Althusser, de passagem-, verifica-se que o autor leu em detalhe e absorveu à sua maneira o debate, propondo uma interpretação pessoal do que denominaria, em outro lugar, "o labirinto da différance". ${ }^{27}$ O paradoxo consiste no fato de que aquela que pode ser vista como a peça teoricamente mais vulnerável do volume, extremamente interessante enquanto manifestação "manifestária” de um lado e evento après coup de outro (dados os seus diversos desdobramentos), reflexão precursora ainda que dê sinais de uma espécie de "esquecimento passivo”, aquela peça mais frágil se tornaria exatamente a mais fértil, no sentido de sua disseminação. Trata-se, sem dúvida, dos passos decisivos em direção à sua própria “abertura gramatológica”, que atinge as melhores performances literárias cerca de uma década depois, em torno de 1980, com os romances (questionadores do gênero romance)

\footnotetext{
${ }^{26}$ Note-se, de passagem, que antes de começar o autor põe em epígrafe um pequeno trecho de L’Archéologie du savoir em que Foucault critica a noção de influência, ao lado de uma frase antropofágica de um romance de Antonio Callado (Quarup), e que, no mesmo Ponta de lança, Oswald denomina a posição de Montaigne como aquela de um "canibal letrado" (78).

${ }^{27}$ Este é, por sinal, um dos lugares privilegiados da experiência desconstrutiva no Brasil: o Glossário de Derrida, com 62 verbetes, resultado de estudo coletivo dos alunos de pós-graduação da PUC-RJ, idealizado e coordenado por Santiago. Entre os participantes encontravam-se intelectuais hoje conhecidos no meio universitário brasileiro, como Evelina Hoisel, Maria Consuelo Cunha Campos e Roberto Correa dos Santos.
} 
Em liberdade e Stella Manhattan. ${ }^{28}$ Frise-se, de resto, que estas observações são feitas não pelo prazer da descoberta de uma contradição em um texto famoso de um autor reputado, e também não a partir do que se poderia chamar uma falta insuperável -porque ela é superada no interior de um mesmo livro-, mas enquanto constatação das metamorfoses de um sistema de pensamento fortemente tributário da nova crítica, assim como da nova literatura, seja ela ou não latino-americana -a literatura de qualquer lugar entre Borges e Desnos, Cortázar e Leiris (escolhidos como exemplos no ensaio), de qualquer lugar entre Europa e América, culturas em choque cujas políticas mais ou menos discricionárias igualmente alimentam o entrelugar do discurso latino-americano.

O autor expõe claramente as razões práticas para a reivindicação de seu entrelugar descolonizante: “O neocolonialismo, a nova máscara que aterroriza o Terceiro Mundo”, propondo, como se disse, a mestiçagem de linhagem oswaldiana e ironizando, com LéviStrauss, a situação bizarra do novo como démodé que era aquela da Europa colonial na América (“O entrelugar” 17). ${ }^{29}$ É aqui, a partir do que chama de "pequenas metamorfoses”, “estranhas corrupções”, onde "o elemento híbrido reina”, que se encontra, segundo ele, a grande contribuição da América Latina à cultura ocidental, postulada acima, em belo desvio da norma, "ativo e destruidor" (18). Com respeito à função do intelectual, em citação silenciosa da carta de Ezra Pound a propósito do mercado literário e de Wall Street, exclama agressivamente: -Falar, escrever é falar contra, escrever contra (19). Lembre-se, a propósito, que o grupo da revista Los Libros poderia inscrever o seu lema, de forma talvez menos retórica porque cada vez mais colada ao "real”, sobre idêntico papel.

Se a condição do etnólogo como herói antiimperialista-os "verdadeiros responsáveis pela desmistificação do discurso da história” (19)- é retomada diversas vezes no ensaio, ela é utilizada enquanto apoio para $a$ questão proposta: seguir o modelo ou marcar sua diferença. Sabe-se, no entanto, que era questão sobretudo de realizar os dois movimentos simultaneamente, e questão também de outro pequeno esquecimento, já que o autor os conhece bem. Seu objetivo nesse caso são os modelos reacionários empregados nas universidade brasileiras - meio ao qual se integrou em definitivo, como professor, a partir de 1974-, aqueles dos estudos de fontes e de influências, próprios do pensamento colonizado, do "saber introjetado” (“Apesar de dependente” 21), recaciltrantes e falidos por completo. A noção de dependência está na ordem do dia e por aí se deveria entender sua investida, a qual não deseja mais que esvaziar, diz ele, a memória enciclopédica do crítico razoável. Irá até mesmo sugerir a necessidade de um estudo psicanalítico sobre o prazer de certos professores universitários no instante do descobrimento de uma influência e de toda sua verdade. Mas ele antes terá descoberto sua própria verdade, uma verdade de vanguarda contra aquela outra, vista como retrógrada: “um novo discurso crítico cujo único valor será a diferença” (20).

Ignorando, ou tendo optado por ignorar, como se viu, a discussão de Derrida sobre o aspecto metafísico da obra de Lévi-Strauss, não deixará de destacar, contudo, o passo

\footnotetext{
${ }^{28}$ Segundo Idelber Avelar, Em liberdade (1981) é “a grande atualização” do programa estabelecido no ensaio do entrelugar (The Untimely Present 140).

${ }^{29}$ Cito a partir da primeira edição do volume, de 1978. A segunda saiu pela editora Rocco (RJ) em 2000.
} 
além ensaiado por Barthes em relação ao estruturalismo tout court através de $S / Z$, por exemplo. Trata-se, nos termos do autor, de um convite à práxis, à prática da escritura (22) e à transformação do leitor em produtor de textos. Daí um compromisso incondicional com o “já-dito”, que menciona a partir de Michel Foucault (a seu lado, à mesa), ${ }^{30}$ ou ainda com o que chama de "já-escrito", a obra segunda, onde o leitor-autor trataria de surpreender o modelo original em suas limitações e lacunas, destruindo-o e rearticulando-o à vontade, sempre de forma agressiva. "O escritor latino-americano [moi] brinca com os signos de um outro escritor” (23), diz, depois de explicar, também de passagem mas de modo sintomático, por que latino e por que americano -na verdade simplesmente "porque é necessário limitar finalmente nosso sujeito de discussão" (21).

Existe um conhecido termo carioca -quer dizer, do Rio de Janeiro, onde se radica Santiago (nascido em Minas Gerais em 1936), lugar ao qual se atribui uma difusa porém afamada tipicidade-de difícil tradução: “desbunde”.É assim, entre o desbunde tropicalista e um certo tipo alegre de seriedade, característico do professor universitário, que descreveria, por exemplo, a escritura do texto segundo no ensaio sobre o “entrelugar”: em parte, trata-se da história de uma experiência sensual com o signo estrangeiro (23). E neste lugar, visto como foco de subversão dos costumes, tudo deve ser possível, exceção feita, claro, à tradução automática: os recursos iriam, então, da paródia ao pastiche à digressão e àquilo que chamaria de "tradução global”, em nome da ótima configuração dos devidos "antídotos" -que é como refere, no ensaio de 1980 (que vem a ser, sabemos, o momento de Em liberdade), as idéias-chave dos personagens escolhidos a dedo para sua "fábula". ${ }^{31}$

Nas entrelinhas do texto, este desbunde acha sua tradução em uma espécie muito nova e ao mesmo tempo muito velha de romantismo: "O signo estrangeiro reflete no espelho do dicionário e na imaginação criadora do escritor latino-americano e se dissemina sobre a página branca com a graça e o dengue do movimento da mão que traça linhas e curvas. Durante o processo de tradução, o imaginário do escritor está sempre em cena” (23). Aí, não à toa, o exemplo é cortazariano, isto é, entre canônico e desbundante: 62, modelo para armar é festejado então por Santiago, que responderia assim, de modo lateral, ao próprio fenômeno do boom, com o que se creditaria, quem sabe, a membro honorário da famiglia da intelectualidade latino-americana com sede em La Habana -ainda que para ser excomungado. ${ }^{32}$ Afinal, o ensaio sobre o entrelugar desse discurso ideal, bem como fundamental e fundador, é também um documento de época.

\footnotetext{
${ }^{30}$ A propósito, como Foucault terá "lido" a leitura deste texto ao mesmo tempo lévi-straussiano e derridiano justo no momento provavelmente mais hostil de sua relação com Derrida? Gayatri Spivak (“Translator’s Preface” lx-lxii) narra a trajetória deste debate, que vai da primeira (1961) à segunda edição (1972) da Histoire de la folie, na qual Foucault decide incluir uma extensa e feroz refutação às críticas de Derrida, o qual o julga ainda preso ao estruturalismo.

${ }^{31}$ Os três antídotos apresentados em “Apesar de dependente, universal” são: a antropofagia cultural "brilhantemente inventada por Oswald de Andrade”; a noção de traição da memória, "eruditamente formulada por Mário de Andrade”; e, em profissão-de-fé vanguardista, a noção "bem pensante e possivelmente ideológica" de corte radical, "recentemente defendido e daquela forma cognominado pelo grupo concreto paulista (a noção é uma apropriação do 'paideuma' poundiano, revista pelo 'parêntese' isebiano)" (22).

${ }^{32}$ Vale notar que coincide neste ponto outra vez com Los Libros, cujo diretor, Héctor Schmucler, em uma rara aparição no corpo da revista, dedica uma resenha a 62 (“Notas” 11); nela apresenta o
} 
Um ensaio por definição não tem fim, já se disse, e não seria necessário repetir. Bastaria por exemplo ler outra nota agregada a posteriori em um pé de página: "Seguimos de perto -o autor esclarece- o ensinamento de Derrida em relação ao problema da tradução em seus pressupostos gramatológicos” (24). E vai citar um trecho de Positions sobre a tradução como prática da diferença entre significante e significado, ou seja, como transformação antes que tradução (31). É o momento de ensaiar o passo mais importante desta leitura na companhia borgesiana de "Pierre Menard, autor del Quijote". É, segundo Santiago, a metáfora ideal para "precisar a situação e o papel do escritor latino-americano, que vive entre a assimilação do modelo original, quer dizer, entre o amor e o respeito pelo já-escrito, e a necessidade de produzir um novo texto que afronte o primeiro e muitas vezes o negue” (25). Menard representaria, assim, o semblante dos escritores latino-americanos, isto é, a sua linguagem em forma de máscara, em sua recusa do espontâneo e em sua escolha consciente do conhecimento enquanto forma de produção. Afinal, “a assimilação do livro pela leitura já implica a organização de uma práxis da escritura”. O “outro” autor do Quixote resume, a seu ver, o mito da liberdade total da criação, "típica da cultura neocolonialista ocidental” (26), uma vez que se instala na transgressão ao modelo, “no movimento imperceptível e sutil da conversão, da perversão, da viravolta” (26-7).

Questão de revoluções antes que de revolução, diria um marxista em pleno uso de sua ortodoxia: Santiago enquanto um pensador pós-marxista -com ênfase, naturalmente, em ambos termos do composto, como o quer Laclau ${ }^{33}$-, à diferença do funcionalismo das leituras de um Roberto Schwarz. ${ }^{34}$ Por isso, ao fim de seu elogio de Menard, fazendo menção à idéia de "formas-prisão" devida ao poeta Robert Desnos -e afirmando que "o artista latino-americano aceita a prisão como forma de comportamento" e "a transgride

romance como modelar para suas propostas de "nova crítica”, já que se trata de uma narrativa nãorepresentativa. Quanto à famiglia de intelectuais, é um dos temas da constelação de períodicos culturais armada por Gilman (cap. III)

${ }^{33}$ Ernesto Laclau, que colaborou em Los Libros antes de deixar a Argentina, ainda em 1969, expõe esta noção em diferentes pontos de sua obra, um dos quais é a entrevista "Del Post-Marxismo al radicalismo democrático" (11).

${ }^{34}$ Como em "Nacional por subtração”, intervenção no Simpósio “Tradição/Contradição”, realizado no Rio de Janeiro em 1985, na qual cita o ensaio "Da razão antropofágica: diálogo e diferença na cultura brasileira" de Haroldo de Campos ao lado do ensaio-chave de Santiago como exemplos da entrada da teoria crítica francesa no Brasil. Schwarz voltaria a mencionar o texto sobre o entrelugar, diante de seu autor, no Colóquio de 1994 em Yale, de maneira redutora (mesmo em castelhano): "Entre paréntesis", diz ele, "no cuesta observar que las ideas de Derrida llegaron al Brasil antes de que se instalara este clima [ie, no decorrer da década de 70, sob os militares, em que "la burguesía ansiaba la asociación con el capital extranjero, que le parecía más natural que una alianza con los trabajadores de su país, los cuales a su vez también preferían a las empresas de afuera”]. Recuerdo un ensayo del amigo Silviano Santiago, aquí presente, que data de 1971, cuyo horizonte aún era otro, anterior al desbarajuste, y por lo demás bastante peor. Entonces la deconstrucción servía para criticar al absolutismo autoritario de la dictadura, así como a la rigidez de la izquierda involucrada en la lucha armada, además de incluir un ligero toque de reivindicación latinoamericanista, cuando cuestiona el primado del centro sobre la periferia, lo que quizás fuera un modo paradójico de dar continuidad al nacionalismo del período anterior. Silviano me corregirá si cabe” ("Referencia nacional” 30-1). Ignoramos se foi dada resposta cabível ao caso. 
como forma de expressão"-, a fala é brava e brevemente concedida a Althusser (27). Recordemos os termos da comparação: como sugere o personagem de Borges (embora claro, tão longe da figura mundana de Borges quanto próximo de seu caráter acefálicoteratológico), o conhecimento nunca suspenderia a criação dos escritores latino-americanos, porque ele é o próprio princípio organizador da produção do texto; sua técnica e sua leitura, portanto, seria culpada como aquela muito conhecida de Althusser sobre Marx na introdução à segunda edição de Lire le Capital (1968): trata-se de um leitor de um outro leitor. O que -sempre paradoxalmente- dará lugar a sua tomada de posição diante do auditório québecois pour la liberté -assim como mais tarde irá postular "um socialismo democrático” em “Apesar de dependente, universal” (18): de um lado, portanto, como já se disse, desde o interior da universidade contra uma certa crítica universitária que não quer ir além das dívidas do escritor a seu modelo central, e, de outro lado, contra "o discurso de uma crítica pseudo-marxista que prega por uma prática primária do texto, observando que sua eficácia seria a conseqüência de uma leitura fácil” (28). É o que se poderia definir como uma variante esquerdista anti-sectária tropical -meramente festiva, na opinião problemática de outro intelectual brasileiro, Augusto Boal, em plenas páginas de Los Libros, como veremos a seguir-, a qual, no entanto, não deixa de empregar seu bom jargão e como que abandonando em breve lapso a sua máscara carioca.

Esta canção de protesto -ainda que ao som de guitarras "maciças” (como diz o autor de Verdade tropical) - desata o refrão grandiloqüente e conclusivo, fórmula-limite e repetitiva do entrelugar, expressão esta que somente é transcrita em sua completude no título do ensaio, e apenas sete anos depois, com a aparição como abre-alas de um livro híbrido, metade civilização, metade barbárie. Mas antes de retomar o refrão (que, como tal, é também lugar de chegada), digamos que o entrelugar segundo Santiago -não obstante sua estratégia teórica, ou por causa dela-, l'entrelieu, como Madame Bovary, c'est moi. O que equivale a enunciar que a sua posição enquanto misto de escritor e professor universitário, de artista e acadêmico, de leitor e autor, é a de um sujeito cuja tarefa vem a ser e segue sendo, ao que tudo indica, a afirmação democrática da diferença, isto é, de uma démocratie à venir ${ }^{35}$ com as contradições que lhe são próprias e que busco agora, a partir de viés inimigo, esboçar.

\section{Tropi(CALI)SMOS} Até os diretores de revistas, gente maldosa
e traquinas com os vates, se enternecem
na presença de teu sobretudo.

Roberto $\mathrm{Arlt}^{36}$

\footnotetext{
${ }^{35}$ Derrida, em recente entrevista concedida a Evando Nascimento, reafirma a idéia de uma democracia baseada na "solidariedade dos seres vivos”, mais além da cidadania e do Estado-nação ("A solidariedade" 12-16).

36 “A um poeta bem vestido”. Revista USP (126). Originalmente em Don Goyo. Buenos Aires, 18 de maio de 1926.
} 
Revista a "novelha” questão do entrelugar do discurso latino-americano, seja diante de um auditório franco-canadense inflamado, seja através do extinto Suplemento Literário de $O$ Estado de S. Paulo, em torno de 1970, tomo a vereda latino-americanista trilhada simultaneamente por Augusto Boal (colaborador do mesmo suplemento), carioca errante que viveu em São Paulo e em Nova Iorque, em Lima e em Buenos Aires, para citar apenas algumas cidades americanas, misto de teatreiro com (então) ideólogo político radical, em cruzada que redundaria em violência e prisão na volta para casa, desde a capital argentina. Fato que Los Libros não deixaria de registrar logo depois. Antes, Boal publicaria nesta autodenominada revista "antiburguesa”, em que o perfil atuante e a verve do personagem caíam especialmente bem, um artigo-panfleto-bomba, de que me utilizo para buscar traçar as suas distintas posturas ideológicas e teóricas. Nele propunha a divisão do teatro brasileiro -e, por extensão, da cultura do país- em três grandes áreas, em uma das quais se encontraria por inteiro o autor do ensaio "Caetano Veloso enquanto superastro” (1972), de Uma literatura nos trópicos, ou do texto "Rock de Carlos para Drummond" (1973), algo mais inédito. ${ }^{37}$ O setor é apodado por Boal-que distribuíra um manifesto antitropicalista em 1967 (embora o negue) na porta de uma faculdade de São Paulo, onde Caetano e Gil falavam-como tropicalismo chacriniano-dercinesco-neorromântico, resultando em uma bela classificação que se pretendia ofensiva. ${ }^{38} \mathrm{~A}$ tensão com a cultura de massas apresentase aí de forma contundente, e as relações explícitas de Caetano Veloso e seu bando com a televisão, por exemplo, são demonizadas. A esse respeito, pode-se afirmar que o grupo de Los Libros se colocava desde o princípio como interlocutor, ainda que sempre crítico e negativo, deste mesmo novo mundo conformado pelos meios de massa, do qual participavam enquanto produtores e consumidores sem dúvida muito mais precavidos, mas não menos vorazes do que os primeiros -a exemplo de seu par, Boal, from Brazil. A própria Beatriz Sarlo dedicaria artigos à tevê e aos meios de comunicação desde sua primeira fase na revista, ${ }^{39}$ para mais tarde, já em Punto de Vista, desenvolver o conceito de "videopolítica", que os tropicalistas anteviram de vários modos, a começar pela instalação fundadora da semente da "Tropicália”, originalmente uma obra de Oiticica, constituída de um caminho de areia em espiral rodeado de verde, conduzindo a um aparelho de televisão permanentemente ligado.

\footnotetext{
${ }^{37} \mathrm{O}$ texto sobre Caetano é uma verdadeira ode ao desbunde, palavra que merece ali explicação: “O desbunde não pode ser definido como se fosse um conceito e muito menos como se tratasse de uma regra de comportamento. É antes um espetáculo em que se irmanam uma atitude artística de vida e uma atitude existencial de arte, confundindo-se” (147). Já o “Rock...” é um texto híbrido e datado, como o demonstra a nota final: "os dois poemas de Drummond são de Sentimento do Mundo (1940). O contraponto sonoro é de Sá, Rodrix e Guarabira, de 1972, entrecortado pela voz de Caetano em 67" (11).

${ }^{38}$ Cujo miolo merece um deslinde, dedicado aos não-iniciados: Chacrinha foi um personagem mítico do imaginário popular brasileiro, um humorista a um tempo grotesco e carismático oriundo de Pernambuco, que se tornaria o primeiro grande apresentador de programa de auditório -“A Buzina do Chacrinha”- da TV Globo na década de 70; já “dercinesco” faz referência a Dercy Gonçalves, centenária atriz e humorista da televisão, do cinema e do teatro brasileiros, igualmente identificada com programas e projetos extremamente populares, e ainda na ativa.

${ }^{39}$ Seu primeiro texto em Los Libros, criticando precisamente uma revista, Nueva Crítica, foi publicado na edição de nº 10, de agosto de 1970 (27).
} 
Do mesmo modo ligado, mas à política do teatro e ao teatro da política, Augusto Boal mereceria real posição de destaque no corpo da edição de janeiro-fevereiro de 1971 de Los Libros, sucedendo a feroz invectiva de Nicolás Rosa contra Victoria Ocampo e o grupo da recém-finada revista Sur, na abertura deste número doble especial, ocasionado pela euforia devida à ascensão de Salvador Allende ao poder no Chile. Já o primeiro parágrafo do artigo, traduzido por René Palacios More, é todo um receituário guerrilheiro para esquerdistas "festivos, serios o sesudos", ou seja, um chamado à união de uma então vasta legião, em um tom entre voluntarioso e primitivesco:

Los reaccionarios buscan siempre con cualquier pretexto, dividir a la izquierda. La lucha que hay que emprender contra ellos a veces es emprendida por ellos en el seno de la propia izquierda. Debido a esto, nosotros -Festivos ${ }^{40}$ serios o sesudos-tenemos que precavernos. Nosotros, los que en distinto grado deseamos modificaciones radicales en el arte y en la sociedad, debemos evitar que diferencias tácticas de cada grupo artístico se conviertan en una estrategia global suicida. Lo que los reaccionarios desean es ver a la izquierda convertida en una bolsa de gatos; desean que la izquierda se derrote a sí misma. Y contra esto tenemos que reaccionar: tenemos el deber de impedirlo. (8)

Como se vê, o Brasil entra na oficina de Los Libros, em plena fase de latinoamericanização, ainda que pela janela: o estentor do teatrólogo carioca antidesbunde trata de escancará-la à base da estridência própria dos discursos panfletários. Detentor da verdade maiúscula, Boal desafia as ditaduras militares, portanto, através de um libelo dedicado às três tendências majoritárias do teatro brasileiro, segundo sua opinião: o "neorealismo”, mais documental que combativo, de, por exemplo, Plínio Marcos; a “exortação” ao povo do Teatro de Arena, de Gianfrancesco Guarnieri, simplificadora, maniqueísta mas "absolutamente indispensável”; e, last and least, conclui com aquilo que identifica de modo bizarro como -vale repetir- "tropicalismo chacriniano-dercinesco-neorromântico". Este monstro cômico-grotesco "pretende ser tudo e não é nada", segundo ele -e "tudo" porque abraçava de maneira "festiva”, de Beatles a João Gilberto, para um exemplo claro e musical. Mas concede à criatura -naquele que é um dos textos mais arbitrários da revista nesse período-certas virtudes, entre as quais a de ter inventado o portunhol. ${ }^{41}$ No entanto, seria para ele a tendência politicamente mais próxima das versões de direita, ao mesclar

\footnotetext{
${ }^{40}$ Nota do original: “En el lenguaje popular se denomina esquerda festiva (izquierda festiva) a la que reúne a los intelectuales con escasa capacidad de agresión. El término surgió, seguramente, pocos años atrás en oportunidad del enfrentamiento de las líneas maoísta y moscovita; tiene, por cierto, connotaciones peyorativas".

${ }^{41}$ Como exemplo extremo -embora o portunhol já apareça em Serafim Ponte Grande (1933)-, lembro a canção "El justiciero", do grupo tropicalista Mutantes, em que Rita Lee Jones clama oswaldianamente por "socuerro" e diz, em portunhol mesclado com italiano, após introdução em inglês: "Io tengo treinta hijos con hambre!/ La guerra me ha estrupato tanto!/ Socuerro, Justiciero, aiútame!” A canção aparece em um disco de 1970, Tecnicolor, gravado em Paris e redescoberto somente em 97. Observo também, en passant, que as primeiras canções da Tropicália foram interpretadas por Caetano Veloso ao lado de um quinteto de (então) escandalosos cabeludos from Buenos Aires, The Beat Boys, depois rebatizados como Os Bichos (o que gostaria de interpretar como uma homenagem a Lygia Clark, conforme o faz o narrador mutante em Stella Manhattan).
} 
Roberto Carlos com Jack [sic] Lennon, por ser importada e “antipueblo”-em uma palavra, são criminosos na concepção de Boal, que conclui pobre e melancolicamente seu artigo, ao afirmar com as letras todas que "a Verdade” estaria exposta na $1^{\text {a }}$ Feira Paulista do Opinião, isto é, do seu próprio teatro. ${ }^{42}$ Importa, ainda, mencionar -a partir daquilo que se julgava a tendência politicamente correta à esquerda, embalada para um periódico não menos razoável na Argentina- uma das notas de rodapé, referência a um ponto central do Rio de Janeiro, a Cinelândia, de conteúdo tão fascistóide quanto pôde ser o regime de Fidel Castro em tempos de violenta caça aos "marginais": o local seria freqüentado "característicamente, por cuanto travesti anda suelto" (grifo meu).

Diria-se que, entre a imposição da ordem e o grito de apelo, tal análise exemplar concentra, antecipa e revela, em um pequeno texto brasileiro em versão castelhana, o forte dogmatismo característico sobretudo dos últimos anos de Los Libros, quando a efervescência política atingiu um auge na Argentina. E é certamente naquele ponto demarcado em tonalidades bizarras pelo dramaturgo brasileiro que se situaria o discurso de Santiago enquanto alvo da veia revolucionária do grupo de dissidentes do comunismo soviético ao qual, seguindo o chamado à união do artigo, todos se somavam, ou deveriam se somar. Ocorre que, sabidamente, a estridência transformava a voz alheia, fosse qual fosse, em direitista, desenvolvimentista, entreguista, progressista ou fascista -e o texto de Boal cai como luva em posse do grupúsculo de intelectuales (cada vez menos) independientes que mantinha a revista portenha. $\mathrm{O}$ autor de Em liberdade seria imediatamente transformado, ou melhor, travestido em escritor-crítico-professor irremediavelmente festivo, membro atuante da cultura brasileira do desbunde -vale dizer, da gente que andava solta-, que se insurge contra o idéario nacional-popular de direita ou esquerda (e que posteriormente se tornaria hegemônica, em outra volta do parafuso). No período mais sectário, posterior à cisão de 1972, o conceito de entrelugar seria taxado de mera abstração “declaracionista”, resultante de mente forjada na fina flor do idealismo, em sua versão burguesa modernizante, estruturalista. Como problema conexo, poderíamos perguntar onde se situariam os atuais subalternistas neste debate, e até arriscar uma resposta, diante da gritante institucionalização da barbárie tropical: com Boal, contra a videopolítica, por uma teoria "antiglobal”, conforme, por exemplo, Alberto Moreiras, ou o mesmo Avelar. ${ }^{43}$

A edição inaugural de 1971 apresenta um espectro heterogêneo de preocupações em uma revista em plena metamorfose. O semiólogo Nicolás Rosa, “cientificista” e “estruturaloso”, conforme a opinião corrente, abre-a no campo da crítica literária, mantendo o verniz teórico barthesiano-althusseriano-lévi-straussiano (ainda não derridiano) que funda a empresa dois anos antes. Logo Boal faz a sua pregação histericamente nacionalista e antiimperialista, sendo sucedido por sociólogos, entre os quais James

\footnotetext{
${ }^{42}$ Note-se também que a tarefa de animação cultural ao mesmo tempo paradoxal e aberta de Santiago nos Estados Unidos, durante 1971, incluiria apresentações de “Arena conta Zumbi”, maior sucesso do Teatro de Arena, ao lado de exposição de Hélio Oiticica e de retrospectiva de filmes de Glauber Rocha, com a presença do cineasta, na State University of New York at Buffalo.

${ }^{43}$ Evidentemente que ambos a anos-luz do panfletarismo de Boal. Ver A exaustão da diferença, de Moreiras, e The Untimely Present, de Avelar, que é outro intelectual oriundo de Minas Gerais em carreira universitária americana.
} 
Petras, Alain Joxe e José Nun, que abordam a política no Chile, por um escritor, Ariel Dorfman, com um texto trôpego e interessado sobre a "actual narrativa chilena”, e por um comunicólogo, Armand Mattelart, sobre a questão da comunicação de massas no país. ${ }^{44}$ Há espaço ainda -lemos número duplo e especial-para uma longa entrevista com líderes do "campamento de pobladores Che Guevara”, de gente sem-terra, além de um texto sobre a economia do país (setor de que os editores não descuidaram); encerradas as páginas chilenas, surge uma homenagem ao filósofo Carlos Astrada, recém-falecido, ${ }^{45}$ assinado pelo discípulo Raúl Sciarreta, e finalmente a continuidade da polêmica sobre as “comunidades terapéuticas”, já que não poderia faltar um pouco de saúde mental -outro setor de permanente consideração na trajetória da revista, da primeira à última edição.

Em abril de 1971, Los Libros, almejando fazer história, concederia novo espaço especial ao teatrólogo brasileiro, sob a forma de uma nota em protesto justamente pela prisão de “Agustín” Boal no Brasil -após ter passado por Buenos Aires com sua companhia teatral em dezembro de 70-, a qual remete a seu panfleto publicado dois números antes. ${ }^{46}$ Há um vasto elogio de sua intensa atividade artística e política, e uma longa citação de uma resposta a um "circunstancial discípulo" sobre o teatro como arte popular e sobre a possibilidade de qualquer artista ou cidadão brasileiro enfrentar o cárcere, como uma premonição: não se trata aí de “forma-prisão”, lembraria um crítico terra-a-terra de Santiago, mas de prisão tout court, com direito a sessões de tortura -que Boal relembra em recente entrevista ("Exilado" 28-33).

Mas, a partir de seu discurso em Los Libros, além da própria presença na revista, pode-se indagar a quem concederia o papel de intelectuais festivos entre os mesmos integrantes de seu núcleo principal. Servindo melhor ou pior, a carapuça recairia bastante provavelmente sobre a dissidência "psicanalítica”, representada depois pelo grupo de Literal, precursor da vertente lacaniana “de combate” em Buenos Aires, sob o influxo de Oscar Masotta, que colabora com Schmucler, divulgando a obra de Freud e Lacan, desde a primeira fase da revista. Quando os pratos se quebram, em 72, o grupo encabeçado por Germán García arremete com decisão contra as “políticas de la felicidad”, características de Los Libros -assim como de Crisis, de Nuevos Aires ou de El Escarabajo de Oro-, em maior ou menor grau, mas de fato cada vez mais intensamente com o novo comitê de redação formado por Sarlo, Altamirano e Piglia. Literal, denominação telqueliana também em sentido literal, investe nas políticas do corpo e da escritura através de uma publicação efêmera que redunda em marginalidade e aversão deliberadas, diante da legibilidade dos textos em geral e da escritura selvagem em particular de Osvaldo Lamborghini -a quem Literal deve grande parte de seu interesse. É de sua lavra, apesar de não existir assinatura ${ }^{47}$

\footnotetext{
${ }^{44} \mathrm{~A}$ vertente sociológica brasileira era a única que dialogava mais efetivamente com a intelectualidade hispano-americana, o que pode ser verificado nas páginas de Los Libros, assim como na Revista Civilização Brasileira. E Mattelart se tornaria sócio de Schmucler, que se exila no Chile, após deixar a revista que havia fundado em Buenos Aires - ou após ser expulso dela, segundo depoimento de Sarlo (13-4).

${ }^{45}$ Astrada, considerado em Respiración artificial "o único filósofo verdadeiro que este país já produziu em toda a sua história”, único ou não, foi o introdutor do existencialismo na Argentina. ${ }^{46}$ A nota, não assinada, saiu em Los Libros no 18 (29).

${ }^{47}$ Germán García "delata” o autor em "La intriga de Osvaldo Lamborghini” (54-7). Em dezembro de 1980, uma nova publicação argentina, Lecturas Críticas, começa a romper o isolamento.
} 
(como em toda primeira metade do primeiro número), o breve texto programático final, "La intriga”, que junta Nietzsche com Sade a partir de Deleuze com Guattari -todos, de um ou de outro modo, na raiz do olhar tropical de Santiago:

\begin{abstract}
Si la cultura es culpable, nuestra inocencia no tiene límites. Abolida la culpa, tomado el goce como horizonte, la voluntad de disparar una ideología contra el blanco de otras ideologías plantea la diferencia como primer problema. Por lo tanto, esta ideología se exhibirá fuertemente marcada. Su marca específica sera la ficción, el relato, el engaño. Se fingirá el saber que no se tiene. Se narrará con cierto ademán aparatoso y teatral - como quien cuenta un cuento a una criatura inteligente- la novela científica importada en esta década oponiéndola a la de la década anterior: a ver qué pasa. $(120)^{48}$
\end{abstract}

São de fato políticas similares -a literatura, o Mal- em que, à sua maneira, o autor de Uma literatura nos trópicos e Em liberdade investe, com o destemor típico dos festivos mais temidos, embora também devamos assinalar os limites desse parentesco: sua atividade críptica se situaria, de modo consciente $e$ inconsciente, ainda uma vez, entre. Ou seja, nesse caso em um lugar que o vincula, de um lado, ao "lacanismo de combate"49 de Literal, no sentido de sua política de vanguarda, que era a da dispersão e a da "festa", e, de outro, à perspectiva histórica e ao formalismo de um Ricardo Piglia, no sentido de seu vanguardismo estético. Algo parecido com o que se dá com o próprio diretor (e mantenedor) de Literal, Germán García, cujo diálogo com Piglia permanece constante, talvez (também) porque este não resistirá ao apoio declarado pela dupla Sarlo-Altamirano ao governo isabel-peronista, tornando-se, já nos estertores de Los Libros, um novo tipo de dissidente, situado entre Mao, Brecht, Arlt e, algo incomodamente naquele momento (embora o nome soe melhor, como o de Mao), Borges.

Agregaria, por fim, que na única vez em que a voz de Osvaldo Lamborghini se faz ouvir em Los Libros, respondendo a uma enquete, é para, justamente, criticá-la de forma bárbara. ${ }^{50}$

Formado por Nora Domínguez, Alan Pauls, Silvia Prati, Renata Rocco-Cuzzi, Adriana Rodríguez Pérsico, Alfredo Rubione e Mónica Tamborenea, seu grupo de novos críticos é tributário daquele de Punto de Vista, que surge em 78 com, outra vez, Sarlo, Altamirano e Piglia. Um de seus entrevistados é Osvaldo Lamborghini (além de Rosa, Sarduy e o mesmo Piglia), quem, a propósito da "flexión literal”, trata de pôr lenha na fogueira: “yo no estaba en Literal, yo hacía junto con Germán García, Literal” ("El lugar del artista. Entrevista a Osvaldo Lamborghini” 49) - e isto provavelmente porque soubesse que García o tinha como um "populista oligárquico" ou um "aristócrata popular" (conforme o texto citado).

${ }^{48}$ Ao abordar "el régimen de la locura” neste texto, O. Lamborghini refere-se explicitamente à noção derridiana ativada por Santiago anos antes: “' 'Había’, en estilo patético, llegado el momento de aceptar que 'entre' la fábrica occidental y los métodos, gráficos y organigramas de la esquizofrenia reina un estado de semejanza; y que esta institución monárquica se ríe sosegadamente de otros supuestos poderes. Porque un texto es un juego ‘entre’ un texto y un juego” (120-1).

${ }^{49}$ A expressão é de Néstor Perlongher.

${ }^{50}$ Transcrevo sua resposta para a questão “¿Existe crítica literaria en la Argentina?”: “No hay crítica literaria en la Argentina; pero creo que la pregunta debe contestarla quien la formula: Los Libros, que pide a un autor que en sesenta líneas (autor que por su parte no se niega a responder) conteste 
VI. SE A REVOLUÇÃo OCORRE

(...) y la habitual protesta idealista contra el caos del mundo sólo delata, de modo invertido, la forma en que aquél que desempeña un papel en ese caos, se las ingenia para vivir.

Jacques Lacan ${ }^{51}$

O encontro desencontrado de discursos setentistas em língua portuguesa e castelhana poderia se dar ainda por meio de duas palavras -na verdade um chavão e uma palavrachave parcamente tolerada, sobretudo à época-, a saber, os conceitos antitéticos de revolução e de pluralismo. O primeiro, como se sabe, representa a principal idéia-força das certezas políticas características do período, tanto de direita-já que os militares aplicaramna de fato, ainda que retoricamente, conforme seu modo de entendê-lo- quanto de esquerda -a qual lhe devotava um fervor mais do que religioso e se supunha detentora indiscutível de sua propriedade. Já o segundo, igualmente problemático, significaria a dissolução de qualquer teleologia.

Em nome da revolução, fruto da cruzada pró-chinesa e antiimperialista, isto é, antiEstados Unidos e anti-União Soviética ao mesmo tempo, o editorial da última edição “especial” de Los Libros, a de n ${ }^{0} 35$-que segue à risca a estratégia guerrilheira lançada na revista por, entre outros, Augusto Boal-, é exemplar a respeito: a China maoísta é tida como espelho para "la liberación nacional y la construcción de una nueva sociedad en la Argentina”, e a revista, com o foco no problema superestrutural, pretende dar uma "imagen verdadera de China”. Conseqüência da visita de Nixon ao país em 1972, propõe-se uma desmontagem da operação publicitária da “prensa burguesa” para neutralizar a Revolução Cultural, modelo de processo político com conteúdo de classe e de ruptura radical pela via armada (tida como absolutamente necessária aos países coloniais e dependentes), e -não menos importante-modelo para a difícil questão das relações da classe intelectual com as massas, suposta solução "para la superación entre trabajo manual e intelectual”. ${ }^{52}$ Contudo, se o ideal revolucionário torna algo unânimes e uniformes os seus discursos nesse momento -porque em Santiago, como veremos, também se faz ouvir-, a idéia de

sobre la literatura, la crítica, sus proyectos y el papel de los medios de información. Como parte del fenómeno, la opinión de Los Libros es más importante que la mía. Podría informar a los lectores a respecto de su propia 'tendencia crítica'. Tengo unas enormes ganas de enterarme a qué se debe semejante hibridaje entre estruturalismo y esa otra cosa que ha invadido sus páginas, especialmente las dedicadas a la crítica de libros. En el número 5 se nos informa, por ejemplo, que un autor posee, según la afirmación de Roa Bastos que firma la reseña, 'un innato talento narrativo', mientras otro (es Carmen Sgrosso quien lo dice) propone a sus lectores un juego 'diabólicamente infantil', en tanto un tercero ha escrito una 'sugerente novela' (Alberto Perrone firma en ese caso). En suma, que la pregunta planea en el vacío. Formularla o contestarla implica cierta dosis de humor siniestro y muchas ganas de jugar a las escondidas” (“La literatura argentina 1969” 12).

${ }^{51}$ A citação aparece em García, Germán Leopoldo. "Música Beat: los jóvenes en el espejo”, no mesmo número (18) de Los Libros em que é noticiada a prisão de Augusto Boal.

${ }^{52}$ Ver editorial de Los Libros ${ }^{\circ}$ 35, mayo-junio de 1974 (3). 
pluralismo os separaria de modo radical, já que é reivindicada pelo mesmo escritor brasileiro (estando na base do conceito de entrelugar) e, por extensão, pela vertente "tropicalista chacriniano-dercinesca-neorromântica”, para dizê-lo ainda uma vez com (contra) Boal, bem como seria rechaçada com veemência pelo grupo de Los Libros, em sua cruzada mais e mais dogmática contra qualquer forma de ecletismo.

Antes de qualquer significante, e de parte a parte, portanto, la revolución. Com a diferença de que a revolução segundo Santiago (embora sua atitude tenha caráter paradigmático) é um instante fugaz, que arriba à segunda metade da década com dificuldade e cada vez menor popularidade. Exemplo disso são as modificações realizadas nas diferentes versões do ensaio sobre o entrelugar. A versão original, de 1971, é praticamente idêntica à definitiva, de 78, com exceção de alguns cortes significativos em seus enunciados finais, em destaque na transcrição a seguir: "O escritor latino-americano nos ensina que, se a Revolução ocorre, o será em difíceis, laboriosas circunstâncias”... $\mathrm{O}$ autor retira este trecho e (se) emenda: o escritor latino-americano nos ensina que “(...) é preciso liberar a imagem de uma América Latina sorridente e feliz, o carnaval e a fiesta, colônia de férias para turismo cultural” ${ }^{53} \mathrm{E}$ conclui, de modo grandiloqüente, com parágrafo muito citado que sofre não menos importantes cortes (no destaque):

Entre o sacrifício e o jogo, entre a prisão e a transgressão, entre a submissão ao código e a agressão, entre a obediência e a rebelião, entre a assimilação e a expressão, entre neocolonialismo e radicalismo -ali, nesse lugar aparentemente vazio, seu templo e seu lugar de clandestinidade, a biblioteca e o campo de batalha, ali se realiza o ritual antropófago da literatura latino-americana. ${ }^{54}$

Tais modificações de substância através de miúdas metamorfoses demonstram, entre outras coisas, como seriam matizados os discursos a partir de meados da década de 70 , quando as verdades políticas -sempre algo perdidas entre os tropicalistas- perdem-se em definitivo. Acaba o caráter messiânico e finalista da empreitada militante radical de esquerda, assim como a dicotomia neo-colonialismo/radicalismo se vê enfraquecida, embora nem colonialismo nem radicalismo deixem, é claro, de existir. Não está mais no ar, não é mais vivida como indiscutível, no entanto, a idéia da redenção amanhã: o campo de batalha da macro-revolução vindoura parece ter sido dominado por um adversário que quase já não se vê -fracasso que, sempre para o bem $e$ para o mal, representou o fim (esperado mas nem sempre assumido) de "una pesadilla teórica y política”, conforme expressão de Sarlo (Entrevista 22).

Restaria a biblioteca, mas também o corpo e a rua, agora sob a forma de microrevoluções, plurais e cotidianas, culturais e comportamentais, trazendo em si a abertura de todo um campo de batalha remodelado, se não mais pacífico certamente mais pacificador,

\footnotetext{
${ }^{53}$ Baseio-me na versão em inglês ("Latin American Literature” 18-9) que diz: "The Latin American writer teaches us that, if the Revolution occurs, it will be under difficult, laborious circumstances. Latin America must be freed from its smiling, touristic image of the 'carnaval' and the 'fiesta'”. As duas sentenças viram uma só, portanto, em português.

${ }^{54}$ A tradução da versão inglesa - concluída com data e local: “Buffalo-Montreal, 1971” - é minha.
} 
povoado de marginais mas já sem heróis, sob as etiquetas (também muito genéricas) de estudos culturais ou de estudos subalternos, com o seu universo de problemas específicos. Ou, no limite, sob nenhuma etiqueta existente no mercado: uma nomenclatura à venir, em algum lugar entre estas vertentes, varadas pelas verdades sociais manifestadas de modo único, ou seja, infinito e indecidível pela literatura.

Não obstante, as lutas continuam: a ver qué pasa.

\section{BiBLIOGRAFIA}

Andrade, Oswald de. "Sol da meia-noite”. Ponta de lança. Obras completas de Oswald de Andrade. São Paulo: Globo, 1991.

Arlt, Roberto. “A um poeta bem vestido”. Revista USP 47 (São Paulo, set.-nov. 2000). Trad. Maria Paula Gurgel Ribeiro.

Avelar, Idelber. The Untimely Present. Postdictatorial Latin American Fiction and the Task of Mourning. Durham/London: Duke University Press, 1999.

Barros Camargo, Maria Lúcia de. “Atividade crítica e periodismo cultural no Brasil contemporâneo” (inédito).

Boal, Augusto. “Situación del teatro brasileño”. Los Libros 15-16(Buenos Aires, jan.-fev. 1971).

“Exilado. Entrevista”. Revista Caros Amigos (São Paulo, abril 2001).

Bosteels, Wouter. “Los Libros: desacralización o resacralización”. América. Cahiers du CRICCAL 15/16. Paris: Presses de la Sorbonne Nouvelle, 1996.

Derrida, Jacques. L'écriture et la différence. Paris: Seuil, 1967. Positions. Paris: Minuit, 1972.

“La loi du genre”. Parages. Paris: Galilée, 1986.

García, Germán L. “Música Beat: los jóvenes en el espejo”. Los Libros 18 (Buenos Aires, abril 1971).

“La intriga de Osvaldo Lamborghini”. Innombrable 2 (Buenos Aires, 1985).

“El exilio de escribir”. Hispamérica XX/59 (Gaithersburg, 1991).

Gilman, Claudia. Entre el fusil y la palabra: dilemas de la literatura revolucionaria. Buenos Aires: Sudamericana (no prelo).

Laclau, Ernesto. “Del Post-Marxismo al radicalismo democrático”. Materiales de Krítica. Santiago do Chile, agosto 1986.

Lamborghini, Osvaldo. “La literatura argentina 1969” (enquete). Los Libros 7 (Buenos Aires, jan.-fev. 1970).

"La intriga”. Literal 1 (Buenos Aires: Noé, novembro 1973).

Leminski, Paulo. Caprichos \& Relaxos. São Paulo: Brasiliense, 1983.

Moreiras, Alberto. A exaustão da diferença. A política dos estudos culturais latinoamericanos. Trad. Eliana Reis e Gláucia Gonçalves. Belo Horizonte: Editora UFMG, 2001.

Nascimento, Evando. “A solidariedade dos seres vivos. Entrevista com Jacques Derrida”. Suplemento Mais!, Folha de S. Paulo (27 maio 2001).

Panesi, Jorge. "La crítica argentina y el discurso de la dependencia”. Críticas. Buenos Aires: Norma, 2000. 
Perrone-Moisés, Leyla. “A floração das revistas”. Suplemento Literário, O Estado de S. Paulo (23 de maio de 1970).

Entrevista com o autor. São Paulo, 15 maio 2000.

“O guardião do templo. Entrevista com Maurice Nadeau”. Suplemento Mais!, Folha de S. Paulo (13 maio 2001).

Piglia, Ricardo. Respiração artificial (1980). Trad. Heloisa Jahn. São Paulo: Iluminuras, 1987.

Entrevista com o autor. Buenos Aires, 29 outubro 1998.

Ribeiro, Darcy. “Venutopias 2003”. Opinião. Rio de Janeiro, 7 março 1975.

Santiago, Silviano. "Latin American Literature: The Space in Between”. Trad. do francês Judith Mayne. Special Studies 48. Council on International Studies, SUNY-Buffalo, dezembro 1973.

“Rock de Carlos para Drummond”. Suplemento Literário do Diário Oficial de Minas Gerais, Belo Horizonte, 28 outubro 1973.

"Vanguarda: um conceito e possivelmente um método”. Alfonso Ávila, Afonso. O modernismo. São Paulo: Perspectiva, 1975. (supervisão). Glossário de Derrida. Rio de Janeiro: Francisco Alves, 1976. Uma literatura nos trópicos. Ensaios sobre dependência cultural. São Paulo: Perspectiva, 1978.

Em liberdade. Rio de Janeiro: Paz e Terra, 1981.

“Apesar de dependente, universal”. Vale quanto pesa (Ensaios sobre questões político-culturais). Rio de Janeiro: Paz e Terra, 1982. Stella Manhattan. Rio de Janeiro: Nova Fronteira, 1985.

"Sobre plataformas e testamentos". Oswald de Andrade. Ponta de lança, op. cit. "Lenha na fogueira (Leituras em francês de Brito Broca)". Remate de Males 11 (Campinas, 1991).

Entrevista com o autor. Rio de Janeiro,18 maio 2000.

Sarlo, Beatriz. Entrevista com o autor. Buenos Aires, 15 junho 1999.

Schmucler, Héctor. "Notas para una lectura de Cortázar”. Los Libros 2 (Buenos Aires, agosto 1969).

Schwarz, Roberto. “Nacional por subtração”. Gerd Bornheim. Cultura Brasileira: Tradição/ Contradição. Rio de Janeiro: Jorge Zahar, 1987.

“La referencia nacional: ¿olvidarla o criticarla?”. Las culturas de fin de siglo en América Latina. Josefina Ludmer, comp. Rosario: Beatriz Viterbo, 1994.

Spivak, Gayatri Chakravorty. “Translator's Preface” (1975). Jacques Derrida. Of Grammatology. Baltimore: Johns Hopkins University Press, 1997 (Corrected edition).

Veloso, Caetano. Verdade tropical. São Paulo: Companhia das Letras, 1997.

Warley, Jorge. "Revistas culturales de dos décadas (1970-1990). Cuadernos Hispanoamericanos 517-519. La cultura argentina. De la dictadura a la democracia (Madrid, jul.-set. 1993). 